doi)" http://dx.doi.org/10.15448/2526-8848.2017.2.28893

\title{
Just a note
}

BEATRIZ BADIM DE CAMPOS*

Pontifícia Universidade Católica de São Paulo (PUC-SP), São Paulio, SP, Brasil

\section{(In honour of William Carlos Williams)}

\author{
I have seen you \\ eating \\ the plums \\ the poetic ones \\ that I have created \\ for you. \\ But I confess \\ I have eaten \\ the poems \\ the ones \\ you wrote \\ and left \\ near \\ the lunchbox. \\ They taste good \\ good \\ enough \\ to my hungry ideas \\ of you.
}

Recebido: 20 de outubro de 2017.

Aceite: 20 de dezembro de 2017.

\footnotetext{
* Doutoranda e mestre do Programa de Estudos Pós-Graduados em Literatura e Crítica Literária da PUC-SP. Professora de Inglês e Literatura. Autora do livro Caminhos Cruzados e Um Lugar ao Sol: o projeto literário de Erico Verissimo, EDUC, 2015.<biacampos@globo.com>.
} 